\title{
Derera Miklós (Nicholas F. Derera) 90 éves
}

Derera Miklós 1919. január 5-én született Budapesten. A kecskeméti Református Gimnáziumban érettségizett, majd a József Nádor Múszaki és Gazdaságtudományi Egyetem Mezôgazdasági Karán diplomázott. Ezt követôen fiatal növénynemesítôként elôször a Monori Magnál, késôbb Mauthner Ödön vetômag vállalatánál tevékenykedett. Akkoriban ezek a cégek igen jelentôs helyet foglaltak el a magyar vetômag szakmában. Késôbb, az ötvenes évek elején vezetô állásokban a Földmúvelési Minisztérium különbözố vállalatainál volt alkalmazásban. Ô irányította Székkutason a gyapotnemesítési kutatásokat, mely tapasztalatok oly fontosakká váltak későbbi életében.

A forradalom és szabadságharcot követően, 1957 szeptemberében érkezett Ausztráliába, mint menekült. Új hazájában, elôször gyári munkás, majd laboratóriumi asszisztensként dolgozott. Innen került New South Wells (NSW) Földmúvelésügyi Minisztériumának Intézetébe kutató agronómusként, hogy kidolgozza hol, és hogyan lehetne gyapotot termelni a régióban. Az állam északnyugati területén sikeresen szervezte meg a gyapottermelést, $\mathrm{s}$ ez a tevékenység igen jelentôs profitot hozott az ott élóknek, $s$ magának az államnak is. A fiatal Derera ezzel nagy nevet, s elismerést szerzett magának a farmerek, az állam irányítói és a tudományos körökben egyaránt. Ebben az idôben a Nandewar-i hegyláncon fedezte föl a róla elnevezett gyapotfajt (Gossypium nandewarense Derera). Rövid idő alatt nagy népszerúségre tett szert, $s$ a farmerek Nick Derera-ként hívták. A Sydney-i Egyetem meghívására 1961-ben Búza Kutató Intézetben kezdte meg 20 éves búzanemesítési pályafutását. 1973-tól 1981 évi nyugdíjba vonulásáig vezette ezt a kutatóhelyet. A búzakutatásokban is a gyapotéhoz hasonló sikereket ért el. Munkatársival több, mint 10 új búzafajtát állított elô a bô húsz év során, melyek közül számos terjedt el nagy területen a termesztésben, $s$ közülük több fajtát használnak a világban a nemesítôk programjaikban (Mendos, Gamut, Gamset, Timgalen, Gatcher, Songlen, Shortim, Timson, Sunkota, Suneca, Sunstar). Ezen évek során, a sikeres fajtaelóállítás 
mellett, intézetében jelentôs módszertani fejlesztéseket is végeztek, melyet az egész világon megismerhettek, $\mathrm{s}$ több helyen alkalmaztak is a nemesítôk. Forradalmasították, gépesítették a tömegszelekciót (Mechanical Mass Selection /MMS/system), s világelsőként vezettek be korai szelekciós technikákat a kalászban csírázás (Preharvest Sprouting) elleni nemesítésben. A búza szárazságtúrésében jelentôs élettani bélyegeket (szálkázottság) az elsôk között kutatta munkatársaival. Derera a hetvenes évek elején egy nemzetközi együttmúködést indított a kalászban való csírázás problémájának leküzdésére, melyből indult a négyévente több száz résztvevôvel folyó tanácskozás, az International Symposia on Preharvest Sprouting in Cereals. E konferencia szervezó bizottságának ma is tiszteletbeli elnöke. Több, mint száz publikációt írt, s ó szerkesztette a „Preharvest Field Sprouting in Cereals" címú, 1989-ben az USA-ban megjelent alapmunkát.

1981-ben 62 évesen ment nyugdíjba, s azóta is rendkívül aktív. Volt munkahelyén nyilvános rendkívüli egyetemi tanár, tudományos magán tanácsadó többnyire kertészeti témakörökben. Munkássága számos elismerésben részesült. Fellow of the Australian Institute of Agricultural Science (1977); Certificate of Appreciation for Services to the Community from the RSL (1979) NSW Branch; Farrer Memorial Medal (1981) (FMM); Rotary Award for Vocational Excellence (1983); Silver Medal by the International Biographical Centre Cambridge (1999). Munkájának talán legnagyobb elismerése volt, amikor a Brit Királynő 1994 júniusában az Ausztrál Rend tagjává fogadta: Member of the Order of Australia (1994) in the Queen's Birthday List (AM).

Derera Miklós tagja annak az évrôl évre létszámában fogyatkozó nagy generációnak, akik a külföldre menekülésüket követôen új hazájukban az állampolgárság mellé hírnevet és dicsőséget szereztek maguknak és az óhazának is. A Sydney mellett éló magyar származású kutató ma is dolgozik, s a világban sokakkal, így velünk, magyarokkal is tartja a kapcsolatot. Feleségével 1946 óta élnek boldog házasságban és sok örömük van fiuk családjában, a négy unokában. Aktivitására jellemző, hogy az elmúlt években is több paprika és dísznövény fajtája kapott Ausztráliában állami elismerést. Most, amikor Derera Miklóst szívből köszöntik a magyar nemesítók és agrárszakemberek, egyúttal további aktív, s alkotó éveket, sok örömet és boldogságot kívánunk neki családja, barátai és munkatársai körében!

Bóna Lajos 